\title{
Evaluating Investments of Power Plant under Uncertainty: Investment Rate Switching and Spark Spread Options*
}

\author{
Ryuta Takashima, ${ }^{\text {a, }}$ Naoya Miyaguchi, ${ }^{\mathrm{b}}$ and Makoto Goto ${ }^{\mathrm{c}}$ \\ a Department of Nuclear Engineering and Management, Graduate School of Engineering, \\ The University of Tokyo \\ ${ }^{\mathrm{b}}$ Department of Industrial and Management Systems Engineering, Graduate School of \\ Creative Schience and Engineering, Waseda University \\ ${ }^{\mathrm{c}}$ Graduate School of Finance, Accounting and Law, Waseda University
}

\begin{abstract}
This paper investigates an investment project of power plants which have the operational flexibility to start-up and shut-down. The project analyzed in this study consists of two sequential phases such as the construction and the operation of the power plant. We develop a simulation model taking into account the uncertainties of construction cost, electricity prices, and fuel prices. Consequently, the project value and the probability distribution of the value are calculated by using the model. Furthermore, we show the effect of the investment rate switching and the spark spread options on the project value.
\end{abstract}

Keywords: Electricity markets; investment rate switching option; spark spread option; real options; simulation model

\footnotetext{
*Received: December 7, 2006; Accepted: May 21, 2008.

${ }^{\dagger}$ Corresponding author. Address: 7-3-1 Hongo, Bunkyo-ku, Tokyo 113-8656, Japan; Phone: +81-3-58412960; E-mail: takashima@n.t.u-tokyo.ac.jp
} 


\title{
不確実性下における発電プラントの投資評価: 投資率変更オプションとスパークスプレッド・オプション
}

\author{
高嶋 隆太 ${ }^{\mathrm{a}}$, 宮口直也 ${ }^{\mathrm{b}}$, 後藤 允 $^{\mathrm{c}}$ \\ a 東京大学大学院工学系研究科原子力国際専攻 \\ $\mathrm{b}$ 早稲田大学大学院創造理工学研究科経営システム工学専攻 \\ $\mathrm{c}$ 早稲田大学大学院ファイナンス研究科
}

\section{1 はじめに}

世界先進各国における規制緩和の潮流の下，我が国においても電力自由化が進展している. 1995 年, 電気事業法の改正により卸電力事業が自由化され, 独立系発電事業者 (IPP) が卸供給 に参入することが可能となった. さらに 2005 年 4 月には, 日本卸電力取引所（Japan Electric Power Exchange: JEPX) が開設され, 日々電力が市場で取引されるようになった.このため 電気事業者は，従来の総括原価主義であった規制下の時のようにコスト回収の保証がなくなり， 発電プラントの投資に対する判断の比重として, 投資リスクや経済性が以前より大きくなった と考えられる. また, IPPやPPS も同様に市場リスクに晒されるものの, 柔軟性のある経営手 法によって市場へ参入することが可能となり, 企業価值を高める投資の機会が増加したものと 考えられる.このような不確実性が存在する電力市場下において, 電力事業・経営の環境に適 した評価手法が必要となる.

近年，不確実性下における投資戦略や事業価值の評価法としてリアルオプション・アプロー チが注目されている $[6,14]$. 本手法を用いることによって, 投資の最適タイミングの決定や柔 軟性のある投資行動の価值創出に関寸る研究が多数行われており, その中でも, 電力経営や発 電事業への応用が多く見受けられる. Pindyck [8] は, 建設費が不確実な状況下における原子力 発電プラントの建設投資の評価を行い，建設の延期や中止に関する不確実性との関係について 分析している. Deng, Johnson and Sogomonian [5] は, スパークスプレッド・オプションの観 点から火力発電プラントの価值について分析を行い, 価格モデルが異なる確率過程のとき価值 を見出している. Tseng and Barz [15] は, 短期における発電プラントの起動停止問題に関し て考察している. Thompson, Davison and Rasmussen [13] は, 電力価格や燃料価格の不確実 
性, さらには, 発電プラントの物理的特性を考慮し, 水力発電プラントや火力発電プラントの 評価を行っている. Gollier, Proult, Thais and Walgenwitz [7] は, 原子力発電プラントの大型 炉と小型炉の建設投資計画に関して，規模の経済と柔軟性の価值の比較により分析を行ってい る. 小田, 松橋, 吉田, 高嶋 [16] は, それぞれの発電プラントの最適投資基準に係る資本費と 変動費の関係から，我が国における電源投資の特性を明らかにしている。このように，発電プ ラントに関する様々なプロジェクトの研究が行われているが，建設や操業を統合的に分析して いる研究や, 発電プラントのライフサイクル評価にリアルオプション的な経営戦略や思考を取 り入れた研究は，ほとんど見受けられない.

発電プラントの価值評価も含めて, 研究開発や資源開発のような複雑な事業の分析や評価を 行うとき, あらゆる状態変数やその不確実性を考慮する必要がある. 状態変数の数が増し, よ り複雑な投資問題を扱うとき, 解析的な解を得ることだけでなく, 評価モデルの式を導出する ことさえ困難になる.このような場合, シミュレーションモデルは有効である. Cortazar and Schwartz [1] は, 多数の不確実な状態変数を扱うことができるシミュレーションの有効性を示 し, 油田開発の評価を行っている.さらには, Schwartz and Zozaya-Gorostiza [12] は破壊的 技術の投資評価, Schwartz and Moon [10] はインターネット企業の価值評価をシミュレーショ ンモデルを用いて行い，その有効性を示している，発電プラントの価值評価を行う場合，建設 費, 燃料費, 運転維持費等あらゆる不確実性が存在する.さらに, 電力市場が開設された現在 において電力価格も不確実性の一つとなった. 不確実性が多数存在し投資判断の基準が困難に はなったが, リアルオプション的な思考を取り入れることにより, 柔軟的な経営戦略から発電 プラントの価值を高めることが可能になると考えられる.

そこで本研究では, 操業時に運転・停止といった柔軟性の高い電源である火力発電プラントに 注目し，建設期間と操業期間の両期間を取り入れた火力発電プラントの事業評価を行うシミュ レーションモデルを構築する，価值評価にあたっては，JEPXでの取引を想定し，完全競争市 場としてモデルを構築している。このモデルを用いることによって, 建設費, 電力価格, 燃料 価格の不確実性やそれぞれの変数間の相関が投資に及ぼす影響を分析する.また，建設期間に おける投資率変更戦略を考慮したときのプロジェクト価值や操業期間のスパークスプレッドに 基づいたときの運転・停止オプションを考慮したプロジェクトの価值を算出する.

本稿の構成は以下のとおりである. 2 節では, 本稿で用いる問題設定を示すと伴に, 状態変数 
のモデルや評価を行うシミュレーションの説明を行う． 3 節では，仮想的な火力発電プラントの 価值の分析を行い，建設時や操業時の戦略的価值を明らかにする．そして，4節を結論とする.

\section{2 モデル}

本節では，火力発電プラントの投資評価に用いる建設，操業のそれぞれの期間における状態 変数と, その不確実性について説明を行い, 評価シミュレーション方法について言及する.

\section{1 建設費の不確実性}

発電プラントの建設期間は 5 年から 10 年と長期にわたることから, 発電プラント評価に建 設期間も含めることは重要である. 建設期間が長期であることだけでなく，プラントの建設に 係る資材等の費用の変動や工事中の予期せぬ事故, さらには規制による工期遅延等の不確実性 要因が多いことから, 建設費の不確実性を考慮する必要がある。そこで本研究では, 費用の外 性的な不確実性や工期遅延等を考慮することが可能な期待残余建設費を状態変数として導入す る [8]. この期待残余費用を用いて, 費用の不確実な状況下での研究開発投資 $[12,11]$ やエネル ギー政策 [3] 等を分析して研究が多く見受けられる. 本研究における，期待残余建設費は以下 の確率微分方程式に従うものとする ${ }^{1}$ :

$$
d K=-I d t+\gamma K d w
$$

ここで $I$ は投資率を表し， $\gamma$ は建設費の不確実性の大きさを表す． $d w$ は Wiener 過程の増分で ある. 建設費の不確実性は建設材料市場や労働市場, 経済状況等に起因し発生する. 初期時点 において予想される発電プラントの建設費を $K(0)$ として, 建設が進むにつれて期待残余建設 費 $K$ は減少する． $K=0$ となった時点で建設完了とする.

\footnotetext{
${ }^{1}$ Pindyck [8] は，技術的な不確実性と投入費用（外性的）の不確実性の 2 つを取り入れ分析している. 本研究では, 研究開発等において影響する技術的な不確実性は小さいものとして, 外性的な不確実性のみを考慮する.
} 


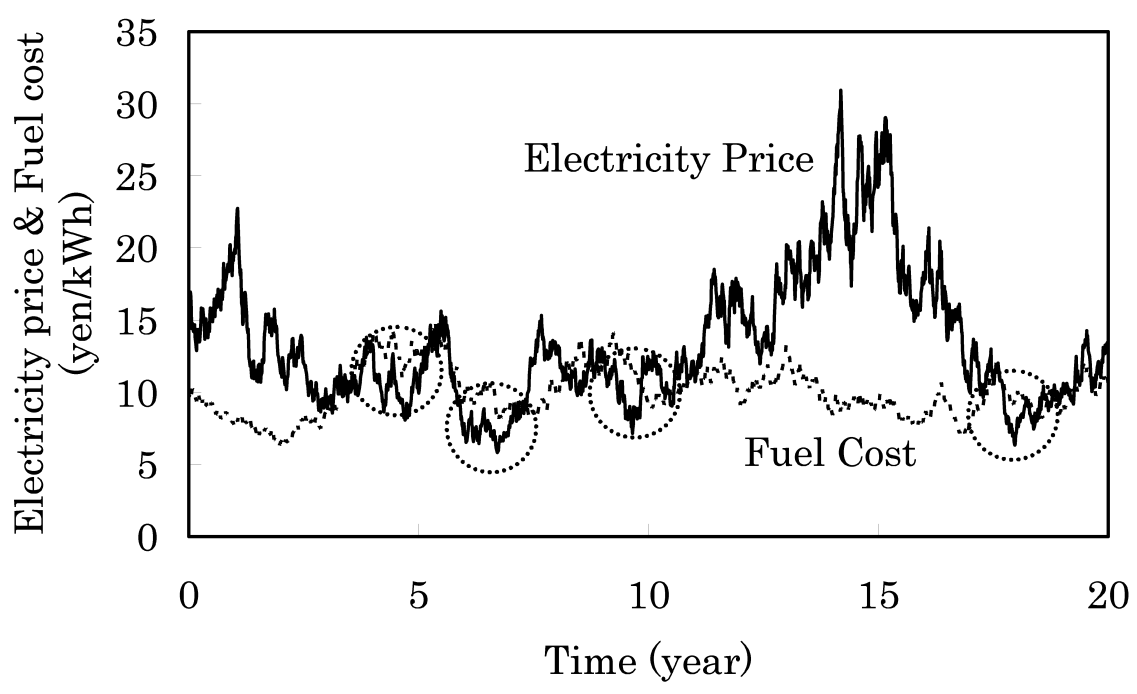

図 1: スパークスプレッド

\section{2 収益の不確実性}

火力発電プラントの建設が完了することにより, その時点から収益が発生する. 収益は, 次 式のように表される：

$$
\text { Profit }=P_{E}-H \cdot P_{F},
$$

ここで $P_{E}$ は電力価格， $H$ は熱消費率， $P_{F}$ は燃料価格であり， $H \cdot P_{F}$ は燃料費である．本研 究では，この電力価格と然料費の差であるスパークスプレッドに基づき発電プラントの運転・ 停止が行われるオプションを考慮する，つまり，スパークスプレッドが 0 より大きいときには 発電プラントを運転し，0より小さいとき，つまり燃料費が電力価格を上回った場合は運転を 停止するものとする. 図 1 において, 電力価格と燃料費のサンプル・パスが示されており, 点 線の丸の部分が運転を停止するところである．従ってスパークスプレッド・オプションのペイ オフは次式のようになる.

$$
\text { Payoff }=\max \left(P_{E}-H \cdot P_{F}, 0\right)
$$


本研究では，このスパークスプレッドに基づく運転・停止の選択権をスパークスプレッド・オ プションという.上でも述べたように, Deng et al. [5] は，このスパークスプレッド・オプショ ンを考慮し発電プラントの価值を算出している.さらに後で示すように，本研究では操業期間 中にかかる運転維持費（O\&M 費）も考慮している.

\section{3 エネルギ一価格モデル}

電力価格やエネルギー価格の推移を確率過程で表す場合, 平均回帰過程を用いて分析する研 究が多く見受けられる $[5,4,9,2]$. そこで本研究においても, 電力価格 $P_{E}$ と燃料価格 $P_{F}$ は 平均回帰過程に従うと仮定する ${ }^{2}$ :

$$
\begin{aligned}
& d\left(\ln P_{E}\right)=\eta_{E}\left(\ln \bar{P}_{E}-\ln P_{E}\right) d t+\sigma_{E} d z_{E}, \\
& d\left(\ln P_{F}\right)=\eta_{F}\left(\ln \bar{P}_{F}-\ln P_{F}\right) d t+\sigma_{F} d z_{F},
\end{aligned}
$$

ここで，(4) 式，(5) 式それぞれ $\eta$ は回帰速度， $\bar{P}$ は長期均衡価格を表しており， $d z_{E}$ と $d z_{F}$ は Wiener 過程の増分である.さらに，電力価格と燃料価格の変動による相関を考慮する：

$$
d z_{E} d z_{F}=\rho_{E, F} d t
$$

ここで $\rho_{E, F}$ は電力価格と然料価格の相関係数である ${ }^{3}$. 例えば，負の相関であれば然料費が下 降したときに電力価格が上昇し，大きな収益を得られるといった状況が考えられる.

\section{4 シミュレーションモデル}

火力発電プラントのプロジェクト価值は, (1) 式, (4) 式, (5) 式の離散化を行い, シミュレー ションにより算出される.

総建設費の現在価值は次式のようになる：

$$
P V_{C}=E_{0}\left[\int_{0}^{\tau} I e^{-r t} d t\right],
$$

\footnotetext{
2電力価格を含めエネルギー価格の特性として平均回帰性の他に, 季節性, 週・月の周期変動, 気温との相関等が挙 げられる. 今後の研究において, これらの特性を価格モデルに反映し, 発電プラントの投資評価を行う予定である.

3 電力価格と燃料価格のパスを発生させるときの乱数をそれぞれ $\varepsilon_{E}, \varepsilon_{F}$ とすると, 相関係数 $\rho_{E, F}$ を考慮したと きの乱数は, それぞれ $\varepsilon_{E}=\rho_{E, F} e_{1}+\sqrt{1-\rho_{E, F}^{2}} e_{2}, \varepsilon_{F}=e_{2}$ である. ただし, $e_{1}$ と $e_{2}$ はそれぞれ独立な標準正 規乱数である.
} 
ここで， $I$ は投資率， $r$ は割引率 ${ }^{4}, \tau$ は建設の完了時点を表しており $(1)$ 式より $K$ が 0 となる 時点であることから確率変数である.

次に，収益の現在価值は次式のようになる：

$$
P V_{P}=E_{0}\left[\left\{\int_{\tau}^{T} \max \left[P_{E}-H \cdot P_{F}, 0\right] e^{-r(t-\tau)} d t\right\} e^{-r \tau}\right],
$$

ここで, $T$ は操業期間として収益が算出されるまでの時点, $\tau$ は建設の完了時点, $P_{E}$ は電力価 格， $P_{F}$ は然料価格， $H$ は熱消費率， $r$ は割引率である. また, 操業期間において修繥費, 人件 費などの O\&M 費を考慮する，O\&M 費は，年率で $T C \cdot R_{O \& M}$ と表せる．TC は建設にかかっ た実際の総費用 5 で，建設期間が確率変数であることから $T C$ も確率変数となる．また， $R_{O \& M}$ は定数で本研究では， $5 \%$ と設定する ${ }^{6}$. 操業期間における O\&M 費の現在価值は次式のように なる：

$$
P V_{O \& M C}=E_{0}\left[\left\{\int_{\tau}^{T}\left(T C \cdot R_{O \& M}\right) e^{-r(t-\tau)} d t\right\} e^{-r \tau}\right] .
$$

これらの式をもとにプロジェクト価值は次式のようになる.

$$
V=P V_{P}-P V_{O \& M C}-P V_{C}
$$

プロジェクト価值 $V$ は投資の意思決定者に対し， $V$ が 0 より大きいときは投資を実行し， 0 よ り小さいときは投資を実行しないという示唆を与える.

このプロジェクト価值を求めるシミュレーションのサンプルパス（それぞれの変数の時間発 展）を図 2 に示した。刻み幅を 0.01 年としてシミュレーションを行っている。点線の左側が建 設期間で, 右側が操業期間となっている. 時点 $\tau$ （約 16 年）で建設が完了し収益が発生する. 操業期間において, 電力価格 $P_{E}$, 燃料費 $P_{F C}$ は確率変数として変動している。この期間にお いて燃料費が電力価格を上回る場所がある（例えば、約 20 年時点）。このようなところにス パークスプレッド・オプションが存在する. 時点 $T$ （約 36 年）でプロジェクトは終了する.こ の一連のシミュレーションを 1 回として，1 万回のシミュレーションより期待プロジェクト価 值が算出される．このモデルによりスパークスプレッド・オプションを考慮するときとしない ときの両ケースの価値を求める.

\footnotetext{
4本研究で扱う割引率は, 評価するプロジェクトや産業特有の外性的に与える割引率である.

5 建設にかかる実際の費用を $T C=\int_{0}^{\tau} I d t$ とする.

6 つまり O\&M 費は総費用の $5 \%$ (年率) である。
} 


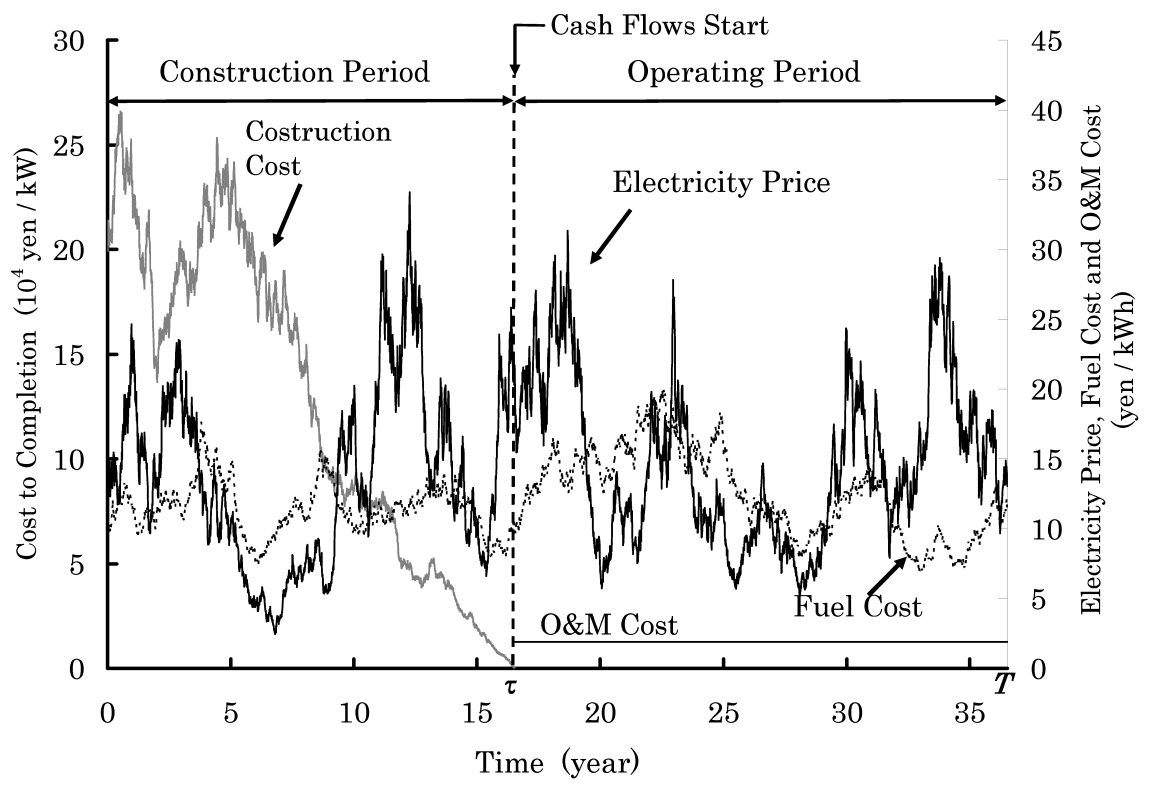

図 2: 火力発電プラント評価のシミュレーションモデル

シミュレーションにあたって，H は一定とし，操業期間は 20 年とした. 各時点のキャッシュ フローの算出にあたっては，法人税等を 0 とすることで，O\&M 費に減価償却費は考慮してい ない.

\section{3 結果と考察}

本研究において分析対象の発電プラントは, 仮想的な火力発電プラントであり, 運転・停止 を行うことが可能な電源を想定している．分析に用いる基本ケースのパラメータは，表 1 に示 されている，燃料費に関して，熱消費率 $H$ が一定であることから $C=H \cdot P_{F}$ として燃料費自 体が確率過程に従うとする。この設定によって, 燃料費の初期值が示されている。 また，電力 価格と燃料費の相関係数が 0 となっているが，相関が正，負のときの分析も行う. 
表 1: モデルプラントの基本ケース・パラメータ

\begin{tabular}{l|c|c}
\hline 割引率 & $r$ & 0.04 \\
\hline 期待建設費 & $K(0)$ & 20 万円 $/ \mathrm{kW}$ \\
\hline 投資率 & $I$ & 1.3 万円 $/ \mathrm{kW}$ \\
\hline 期待建設費のボラティリティ & $\gamma$ & 0.2 \\
\hline 初期電力価格 & $P(0)$ & 15 円 $/ \mathrm{kWh}$ \\
\hline 電力価格の回帰率 & $\eta_{P}$ & 0.2 \\
\hline 長期均衡価格 & $\bar{P}$ & 15 円 $/ \mathrm{kWh}$ \\
\hline 電力価格のボラティリティ & $\sigma_{P}$ & 0.5 \\
\hline 初期燃料費 & $C(0)$ & 10 円 $/ \mathrm{kWh}$ \\
\hline 燃料費の回㷌率 & $\eta_{C}$ & 0.2 \\
\hline 燃料費の長期均衡值 & $\bar{C}$ & 10 円 $/ \mathrm{kWh}$ \\
\hline 燃料費のボラティリティ & $\sigma_{C}$ & 0.2 \\
\hline 電力価格と燃料費の相関係数 & $\rho_{P, C}$ & 0 \\
\hline 運転・維持費用比率 & $\xi$ & 0.05 \\
\hline
\end{tabular}

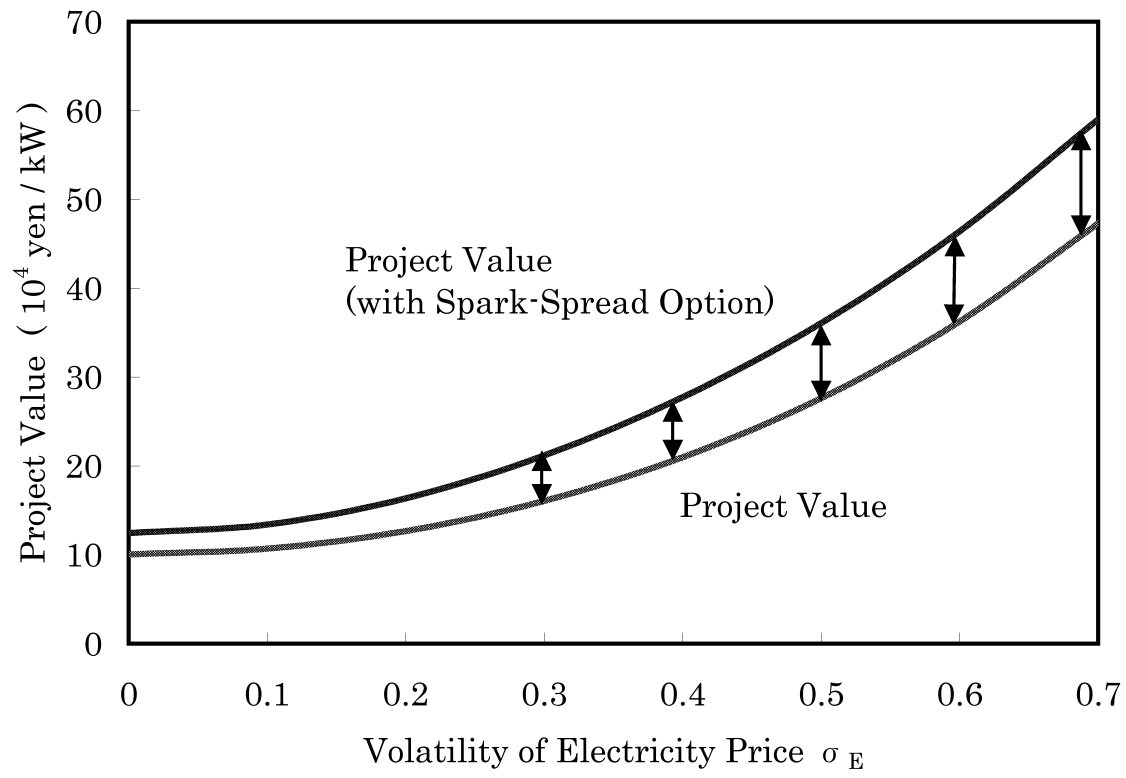

図 3: スパークスプレッド・オプションの価值 


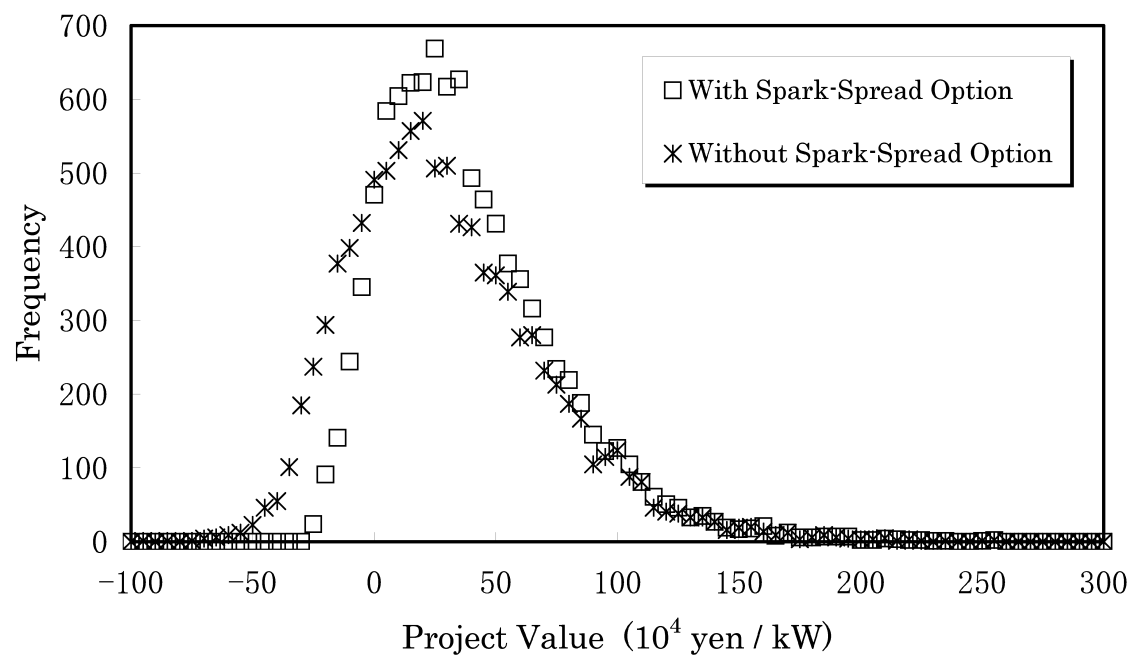

図 4: 事業価值の分布

\section{1 スパークスプレッド・オプションの評価}

図 3 は，電力価格のボラティリティとプロジェクト価值の関係を示している．上がスパーク スプレッド・オプションを考慮したときのプロジェクト価值で，下が考慮していないときのプ ロジェクト価值である. 両方の場合においても, 電力価格のボラティリティが増えることによ り，プロジェクト価值が大きくなることが分かる，スパークスプレッド・オプションを考慮す ることによりスパークスプレッドが負の時には運転を停止し損失を回避するため, 電力価格の ボラティリティが大きくなるにつれて，スパークスプレッド・オプションは経済的価值を増す ことがわかる. JEPXのような電力取引市場が創設され, さらに取引量が増し, 電力価格の不 確実性が大きな状況下において, 火力発電プラントの持つスパークスプレッド・オプションは 経済的な価值を持ち, 不確実性の大きさによりその価值を増すことが示唆される.

図 4 は, 電力価格のボラティリティが 0.5 のときの事業価值の分布をスパークスプレッド・ オプション保持の有無のそれぞれのケースおいて比較したものである.オプションを考慮する ことによって事業価值分布の幅は小さくなることが示されている. それぞれの期待事業価值は 36.10 円 $/ \mathrm{kW}, 27.62$ 円 $/ \mathrm{kW}$ であり, 期待価值の分散は 36.70 円 $/ \mathrm{kW}, 41.23$ 円 $/ \mathrm{kW}$ である. 特 


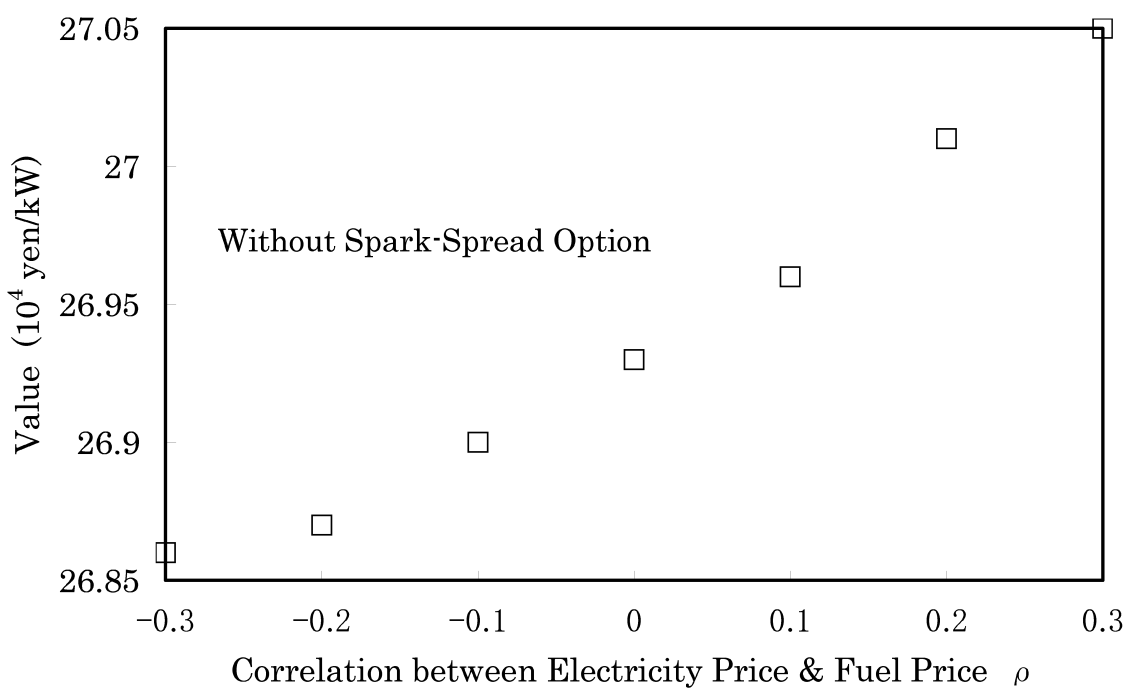

図 5: 電力価格と燃料価格の相関の影響

に, 負の価値になる確率が $26.73 \%$ から $13.15 \%$ 一と減少しており，期待事業価值の確率は増加 していることが分かる。これらの図から不確実な状況に適応するプラントの柔軟性は重要性を 増し, 市場拡大と伴にこの様な柔軟性を計画し保有する必要性は大きくなるといえる.

図 5 はプロジェクト価值に対して，オプションが考慮されていないときの電力価格と燃料価 格の確率的変動の相関の影響を示したものである. 2 変数の相関が正の場合は, 燃料価格の上 昇が電力価格の上昇に大きく影響し，プロジェクト価值の増加へと導く．また，価格が下降す るときはプロジェクト価值に影響を及ぼさない，つまり，スパークスプレッドの負の機会が少 ないことを示している.

図 6 は電力価格と然料価格の相関の影響をオプション保持の有無の両ケースにおいて比較し たものである．この図の縦軸は図 5 の縦軸とスケールが異なっている．相対的にスパークスプ レッド・オプションを考慮していないときのプロジェクト価值には，あまり影響はみられない が，スパークスプレッド・オプションを考慮したときのプロジェクト価值に対して，正の相関 のときは，電力価格の上昇が燃料価格の上昇により打消され，プロジェクト価值の減少を導い ている．負の相関のときは，電力価格の上昇が燃料費の下降へとつながりスパークスプレッド を大きくすることや，その逆の状態のときは，オプションを行使することで，プロジェクト価 


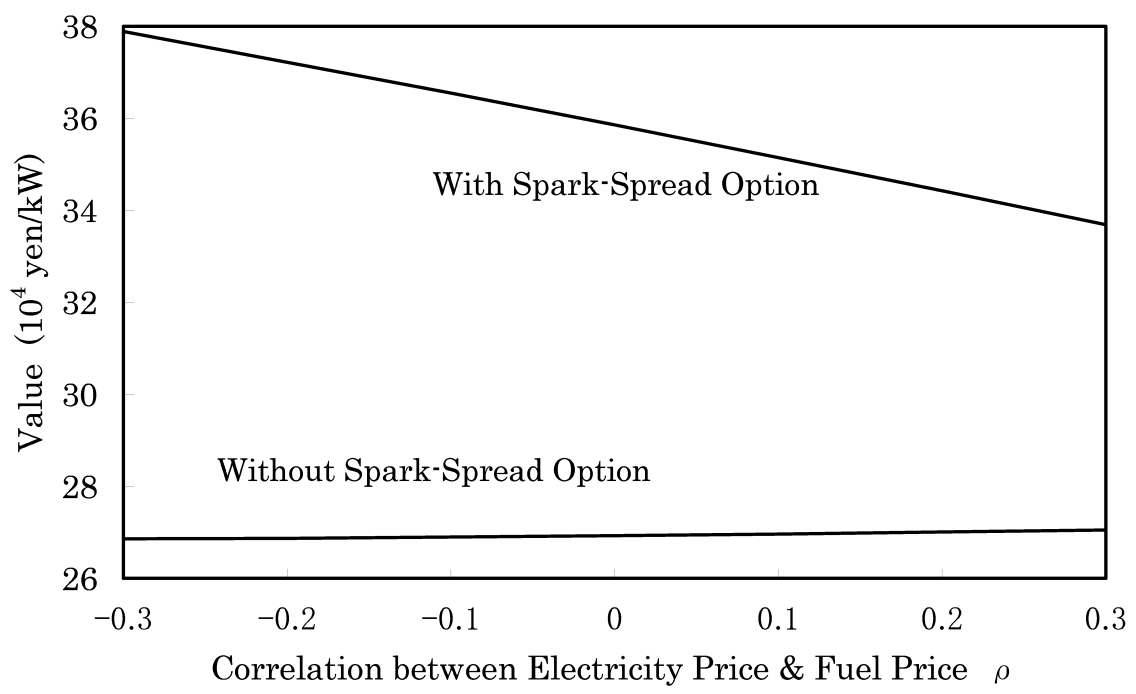

図 6: 相関の影響の比較

值に対して正の影響が大きく現れている.このようにオプションを保持している発電プラント においては，正の相関が大きいとき，相対的に価值が減少するが，

\section{2 投資率変更戦略}

オプションを保持していない発電プラントと比べ，価值が高いことが分かる．また，電力価 格と然料価格との相関を市場で観察し，運転・停止戦略を調整することにより価值を高めるこ とが可能であることを示唆している.

これまで操業期間における柔軟な事業戦略である運転・停止オプションを考えてきた。しか しながら，建設期間においても柔軟性のある経営戦略をとることにより価值を高めることが考 えられる，例えば，建設期間において収益が高いと予想したとき，建設の完成を早めることに よって，収益が高い状態で操業期間に入る可能性を高める．また，収益が低いときに建設の完 成を遅らせることにより，収益が低い状態で操業期間に入る可能性を低くする，これは発電プ ラントの収益の源泉である電力価格の動向を観察することにより可能であると考えられる.

そこで本節では, 電力価格に焦点を当て, 電力価格がある上限值に達した場合に投資率を上 


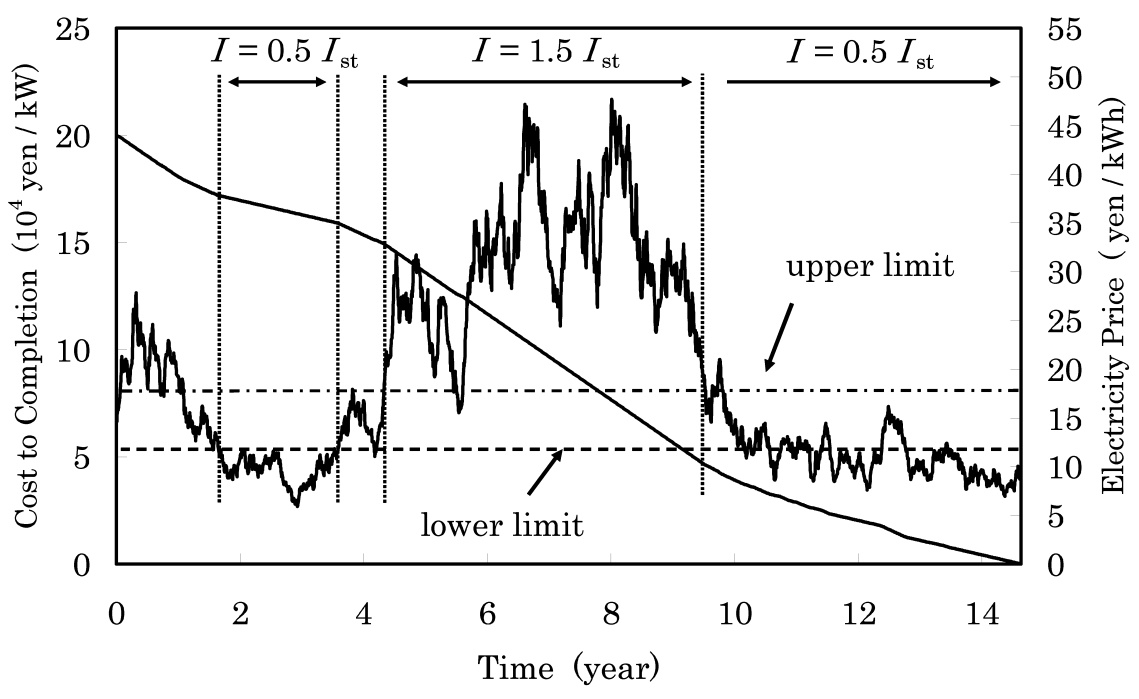

図 7: 投資率変更戦略

げ，ある下限值に達したら投資率を下げる投資率変更戦略を考える. 通常の投資率を $I=I_{s t}$ と して，電力価格が上限值に達したときの投資率を $I=1.5 I_{s t}$ とし，下限值に達したときの投資 率を $I=0.5 I_{s t}$ とする。これを表現したものが図 7 である. 図 7 は費用の不確実性が $\left.0 （ \gamma=0\right)$ のときのものである.

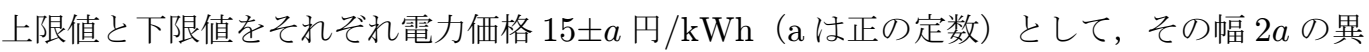
なる戦略を考える。それぞれ異なった戦略のときの事業価值を算出したものが図 8 である。こ

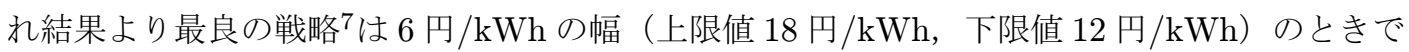
事業価值 40.14 円 $/ \mathrm{kW}$ のときである.

この最良の戦略を考慮したときの事業価值を電力価格のボラティリティ別に算出したものが 図 9 である. スパークスプレッド・オプションのみを考慮したときの方が，価值増加への寄与 が大きいが，建設期間の投資率変更オプションによって，さらに事業価值が増し，ボラティリ ティが高くなるにつれてこれが顕著になっていることが分かる．これは，操業期間における運 転・停止戦略だけでなく, 建設期間における戦略の必要性を示しており, 先行研究では分析さ

\footnotetext{
${ }^{7}$ Schwartz and Zozaya-Gorostiza [12] も指摘しているように，本研究において得られる解は，ある条件に対する シミュレーションによって得られていることから最適解ではない. ある与えられた条件においての最適行動として「最 良の行動」としている.
} 


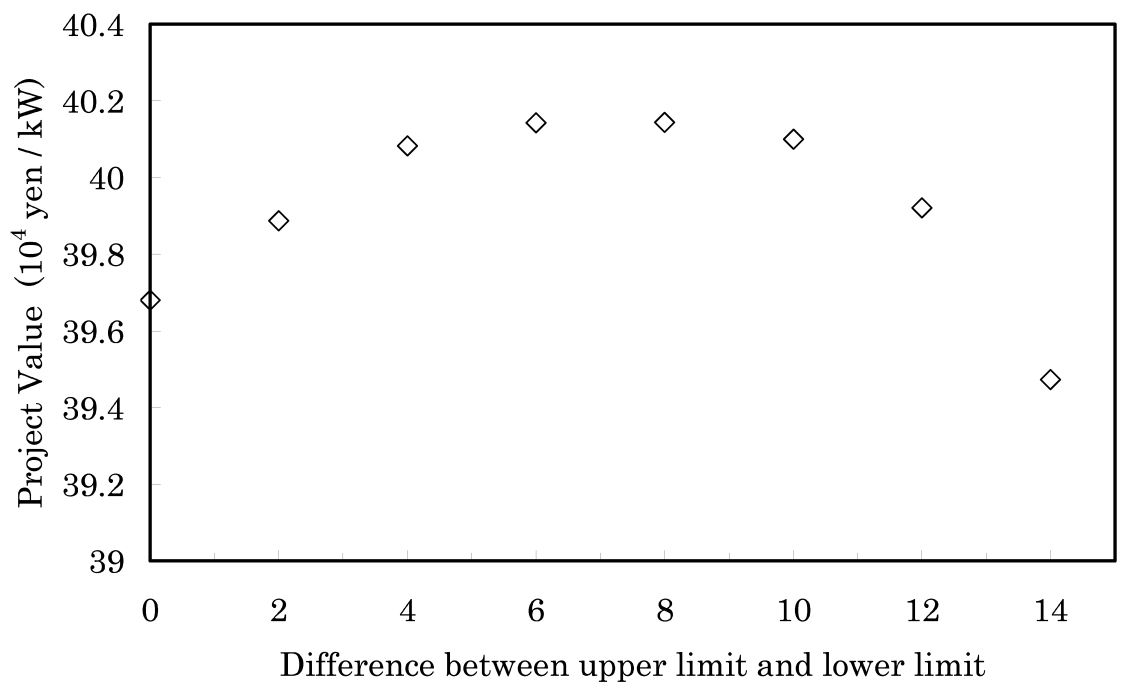

図 8: 投資率変更戦略下での事業価值

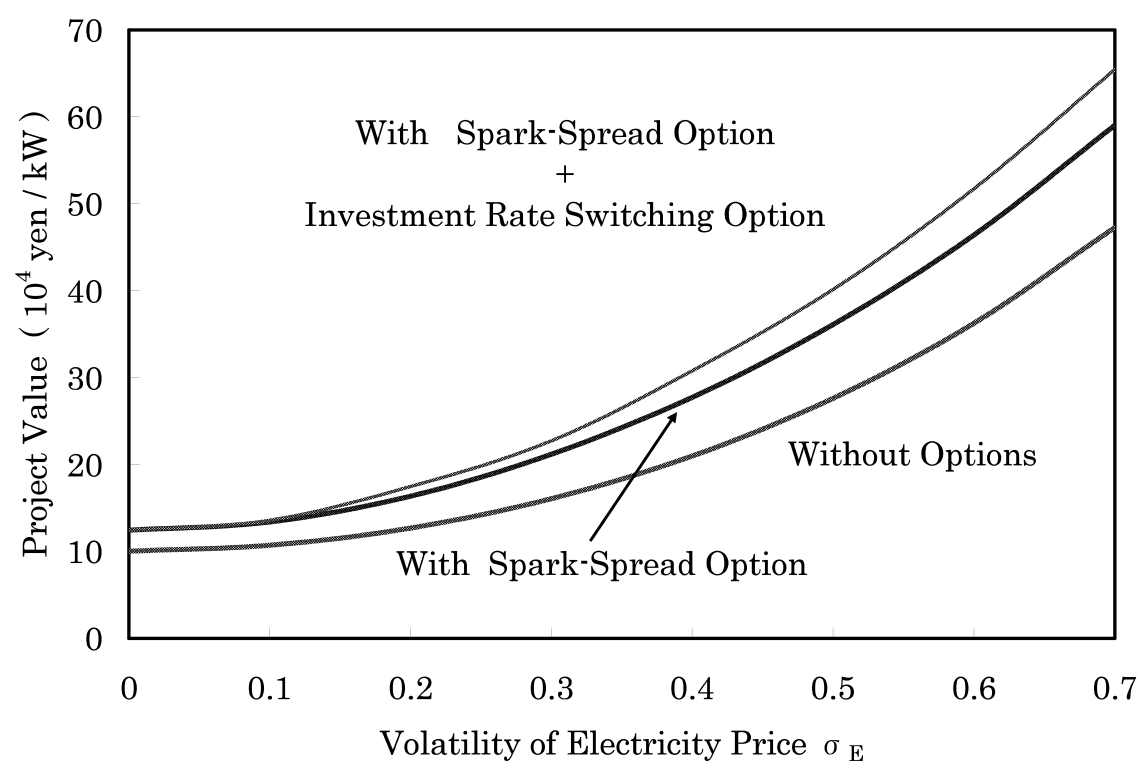

図 9:2つのオプションの影響 
れてこなかった，建設と操業両期間のにおける戦略的な事業価值を示している.

\section{4 おわりに}

本研究では, 火力発電プラントの事業評価に対し, 建設費, 電力価格, 燃料価格の不確実性 を考慮したリアルオプション・アプローチによるシミュレーションモデルを構築した. これに より, 電力価格の不確実性や変数間の相関と事業価值の関係を示すことが可能となった. さら に，スパークスプレッド・オプションや投資率変更オプションを考慮した場合としない場合を比 較することによりオプション価值が算出され, 柔軟性のある事業戦略の正当性を示した。発電 プラントの操業によってだけでなく, 収益が発生しない建設期閒においても戦略的な意思決定 を行うことで，価值創造へとつながることが分かった，JEPXにおける取引が活発になり，独 立電気事業者（Independent Power Producer: IPP）の新規参入が注目されている中，IPPは， 本研究のような建設期間における戦略的な経営方針をとることにより参入の可能性を高めるこ とが可能であるということを示唆している。

本研究のモデルにおける電力価格モデルは，先行研究と同様な平均回帰過程としたが，今後， JEPX の電力価格分析を行うことでモデル化を行い, 本研究の評価モデルに, その価格モデル を組み込むことで投資の分析を行う。また，本研究では，一つの発電プラントに関する投資評 価を行ってきたが，今後は，様々なプラントを有する電力会社がリアルオプション的な思考に よって投資行い，その競争行動によって電力価格が変化するような分析をエージェントシミュ レーションを用いて行う.

\section{謝辞}

本稿を作成するにあたり，高森寛教授には大変貴重なコメントを頂いた。この場を借りて謝 意を表したい.

\section{参考文献}

[1] Cortazar, G. and Schwartz, E. S. (1998). Monte Carlo Evaluation Model of an Undeveloped Oil Field. Journal of Energy Finance 63 Development, 3, 73-84. 
[2] Cortazar, G. and Schwartz, E. S. (2003). Implementing a stochastic model for oil futures prices. Energy Economics, 25, 215-238.

[3] Davis, G. A. and Owens, B. (2003). Optimizing the level of renewable electric R\&D expenditures using real options analysis. Energy Policy, 31, 1589-1608.

[4] Deng, S. and Jiang, W. (2005). Lévy process-driven mean-reverting electricity price model: the marginal distribution analysis. Decision Support Systems, 40, 483-494.

[5] Deng, S. Johnson, B. and Sogomonian, A. (2001). Exotic electricity options and the valuation of electricity generation and transmission assets. Decision Support Systems, 30, 383-392.

[6] Dixit, A. K. and Pindyck, R. S. (1994). Investment under Uncertainty. Princeton University Press, Princeton.

[7] Gollier, C. Proult, D. Thais, F. and Walgenwitz, G. (2005). Choice of nuclear power investments under price uncertainty: valuing modularity. Energy Economics, 27, 667685.

[8] Pindyck, R. S. (1993). Investment of uncertain cost. Journal of Financial Economics, 34, 53-76.

[9] Pindyck, R. S. (2004). Volatility and commodity price dynamics. Journal of Futures Markets, 24, 1029-1047.

[10] Schwartz, E. S. and Moon, M. (2000). Rational Pricing of Internet Companies. Financial Analysts Journal, 56, 62-75.

[11] Schwartz, E. S., and Moon, M. (2000). Evaluating Research and Development Investments. In Brennan, M.J. and Trigeorgis, L. (eds). Project Flexibility, Agency, and Competition, Oxford, Oxford University Press, 85-106.

[12] Schwartz, E. S. and Zozaya-Gorostiza, C. (2000). Evaluating Investments in Disruptive Technologies. UCLA Woking Paper. 
[13] Thompson, M. Davison, M. and Rasmussen, H. (2004). Valuation and optimal operation of electric power plants in competitive markets. Operations Research, 52, 546-562.

[14] Trigeorgis, L. (1996). Real Options. MIT Press, Cambridge.

[15] Tseng, C. L., and Barz, G. (2002). Short-term generation asset valuation: A real options approach", Operations Research, 50, 297-310.

[16] 小田潤一郎, 松橋隆治, 吉田好邦, 高嶋隆太 (2005). 「投資リスクを踏まえた電源の投資 問題」,『日本エネルギー学会』， 84, 134-141. 